\title{
Flowering biology and pollen production of four species of the genus Rosa L.
}

\author{
Beata Żuraw, Aneta Sulborska*, Ernest Stawiarz, Elżbieta Weryszko-Chmielewska \\ Department of Botany, University of Life Sciences in Lublin, Akademicka 15, 20-950 Lublin, Poland
}

\begin{abstract}
Wild growing rose species are of great importance as a source of pollen for insects. Oil extracted from the petals of various Rosa species is used in perfumery, cosmetic industry, and therapeutics. In our study, we compared the flowering duration and flower lifespan, the number of stamens and pistils, the mass and size of pollen grains as well as the anatomical features of the petals of four Rosa species: $R$. canina, $R$. $\times$ damascena, $R$. gallica, and $R$. rugosa. Moreover, we examined the pollen loads collected by bumblebees foraging on rose flowers in order to determine the attractiveness of pollen of this genus to insects. We showed the flower lifespan to vary (3.5-8 days) in the roses studied and revealed high variation in the number of stamens (82-260) and pistils (17-65) as well as in the mass of pollen produced. The flowers of $R$. rugosa produced the highest amount of pollen (26.7 mg per flower), while the flowers of $R$. canina the least (3.3 mg per flower), which is associated with differences in the number of stamens developed in the flowers between these species. The largest pollen grains were found in $R . \times$ damascena and R. gallica. We demonstrated that $R . \times$ damascena produces the thickest petals and that scent-emitting papillae found on the adaxial surface of the petals differ in size and shape in the rose species investigated.
\end{abstract}

Keywords: Rosa; flowers; functional morphology; petal structure; scent emission; pollen mass; pollen loads

\section{Introduction}

The genus Rosa includes about 200 species growing only in the northern hemisphere. According to some authors, 16 species of this genus are found in the wild in Poland [1], while some other ones mention 32 species [2]. Due to their androecium of numerous stamens, wild rose species provide food resources for insects as a rich source of pollen [3]. Rosa canina L. belongs to the most common species found in Poland, whereas Rosa gallica L. is a very rarely encountered species that is fully protected $[2,4]$.

In the world, rose oil is currently obtained for industrial purposes from several rose species. Rosa gallica L., R. ×damascena Mill., and $R$. rugosa Thunb., inter alia, are mentioned among them [5]. The two latter species belong to introduced plants in Poland, while $R$. rugosa has the status of invasive plant in Europe [6-8]. Rose oil is used in perfumery, cosmetic industry, and therapeutics. It exhibits antiseptic and antiinflammatory activity, and accelerates healing of wounds $[5,9,10]$. Rose oil is also used in aromatherapy, since it has a sedative and mentally stabilizing effect [11]. The scent of the flowers of individual rose species may significantly vary.
Rosa species with rose, fruity, spicy, musky and violet scent are mentioned [5].

Dobson et al. [12] showed the scent of the R. rugosa flower to be determined by qualitatively different oils emitted by the sepals, petals, stamens, and pollen. Bergougnoux et al. [13] found that in Rosa $\times$ hybrida both surfaces of the petals emit odorous substances. Similar results were obtained for R. rugosa by Sulborska et al. [14]. The above-mentioned authors demonstrated the presence of essential oils both on the adaxial surface of the petals, covered with papillae, and on the abaxial surface on which flat epidermal cells were found.

The aim of our study was to evaluate the apicultural value of 4 Rosa species, including three species grown for oil. The floral morphology, including the number of stamens, and the mass of pollen produced by the stamens was compared. The petal structure was analyzed, with special attention to the micromorphology of papillae emitting odorous substances which are found on the adaxial surface of the petals, to show whether an intense emission of scent is associated with some special structural features of the epidermis. Microscopic analysis of pollen loads collected by bumblebees visiting the flowers of $R$. rugosa and $R$. $\times$ damascena was performed in order to determine the share of Rosa pollen in them.

*Corresponding author. Email: aneta.sulborska@up.lublin.pl

Handling Editor: Barbara Łotocka 


\section{Material and methods}

The study was carried out in the Botanical Garden of the Maria Curie-Skłodowska University in Lublin in 2013. Observations included the flowers of 4 Rosa species: $R$. canina L., R. gallica L., R. rugosa Thunb., and R. ×damascena Mill.

\section{Flowering biology}

The phenology of flowering was investigated using the method by Łukasiewicz [15]. The time when $10 \%$ of flowers on a shrub were open was considered to be the beginning of flowering for each species, full flowering was when about $25 \%$ of flowers were open, while the end of flowering when $75 \%$ of flowers were found to be senescent (the end of the effect of mass flowering). The date of senescence of the last flowers was considered to be the end of flowering. Flower diameter was measured in 30 flowers. The number of petals, stamens and pistils was estimated in 10 flowers. The stamens were excised from the flowers in order to determine pollen production.

\section{Petal anatomy}

Sections from newly open flowers $(0.5 \times 0.5 \mathrm{~cm}$ from the middle part of petal) were fixed in $2 \%$ glutaraldehyde with $2.5 \%$ paraformaldehyde in $0.75 \mathrm{M}$ phosphate buffer with a $\mathrm{pH}$ of 6.8 at a temperature of $4^{\circ} \mathrm{C}$ for $12 \mathrm{~h}$. Next, the samples were dehydrated in an ethanol series, dried at the critical point in liquid $\mathrm{CO}_{2}$ and coated with gold using an EMITECH K 550x sputter coater. The preparations were observed under a TESCAN/VEGA LMU scanning electron microscope at an accelerating voltage of $30 \mathrm{kV}$.

\section{Examination of pollen}

Pollen viability was estimated using acetocarmine slides. For each species, viable (staining pink) and non-viable (colorless) pollen grains were counted under a microscope in 4 successive longitudinal transects of the slides, up to a total of 100 grains in each transect.

The size of pollen grains was determined based on measurement of the polar (P) and equatorial (E) axes in semipermanent slides with glycerol-gelatin mounting medium. The size was estimated using light microscopy with an eyepiece micrometer in 30 replicates for each species.

\section{Pollen production}

Pollen production was estimated using the ether method by Warakomska [16] with the alcohol modifications of Szklanowska [17]. The study material consisted of buds picked at stamen maturity before pollen release (excluding the first anthers beginning to shed pollen). A hundred anthers were placed in each of previously tared glass microcylinders. The microcylinders with fresh anthers were inserted in the drier at a temperature of about $30^{\circ} \mathrm{C}$. After 14 days the dried anthers were immersed twice in dimethyl ether. A 96\% alcohol was then instilled into the microcylinders to thoroughly wash out the remnants of pollen from the anthers and subsequently the remains of the anthers were removed. After the alcohol evaporated, the pollen samples were placed in the laboratory oven, dried to constant mass, and then weighed. Four samples of 100 anthers were collected for each species. The mass of pollen obtained was calculated per 100 stamens and per 10 flowers.

\section{Analysis of pollen loads}

To determine the mass of pollen loads formed by bumblebees, five individuals were captured. Under field conditions, pollen packages were removed from the baskets on the tibiae of the third pair of legs and the insects were released to the environment. After several days the pairs of air-dried pollen loads were weighed and their color was determined using $A$ dictionary of color by Maerz and Paul [18]. Preparations were then prepared following the recommendations of Smaragdova [19]. For this purpose, each pollen load was ground with 1 $\mathrm{ml}$ of distilled water with glycerol at a ratio of 1:1 until fine. Subsequently, permanent microscope slides were prepared. The pollen spectrum of each sample was examined under a Nikon Eclipse E600 light microscope at a magnification of $40 \times 15$. At least 300 grains were counted in each slide, according to the recommendations of Moar [20]. These grains were identified and assigned to species, genus, type of structure, or family. During the microscopic pollen analysis, reference slides and available keys were used [21-25]. The standard deviation $(S D)$ was calculated in an Excel spreadsheet.

\section{Results}

\section{Flowering biology}

The rose species studied flowered at similar times over the period from May 21 to July 3 (Tab. 1). Rosa rugosa bloomed first (May 21), followed by R. canina (June 2), while the other two species entered the flowering period latest (June 8). The flowering of $R$. canina and $R$. gallica lasted slightly less than 3 weeks, in the case of $R$. $\times$ damascena the flowering period was almost 4 weeks, whereas for R. rugosa it was as much as 6 weeks. Among the taxa investigated, the flowers of $R$. canina had the shortest lifespan (3.5 days), the flowers of $R$. gallica and R. rugosa were characterized by a medium

Tab. 1 Flowering phenology and flower lifespan of the four Rosa species.

\begin{tabular}{lccc}
\hline Species & Flowering time & Flowering duration (days) & Flower lifespan (days) \\
\hline Rosa canina & June $2-19$ & 18 & 3.4 \\
Rosa $\times$ damascena & June $8-$ July 3 & 26 & 8.0 \\
Rosa gallica & June $8-26$ & 19 & 4.5 \\
Rosa rugosa & May $21-$ July 2 & 43 & 5.0 \\
\hline
\end{tabular}


lifespan (4.5-5 days), while the flowers of $R . \times$ damascena bloomed longest (8 days; Tab. 1 ).

\section{Floral morphology}

The flower diameter of the studied species ranged 5.5-11.0 $\mathrm{cm}$ (Tab. 2). The R. rugosa was characterized by the largest flowers (Fig. 1a, Fig. 2a, Fig. 3a, Fig. 4a).

In the case of three species studied, the number of petals was fixed and it was 5; only in the hybrid Rosa $\times$ damascena the number of petals ranged between 22 and 35, with a mean number of 28 (Tab. 2, Fig. 2a). The mean number of stamens was in the range of 83-260, whereas the number of pistils in the range of 17-65 (Tab. 2). The flowers of R. rugosa had the most stamens and pistils. The flowers of $R$. canina produced the least generative parts. Compared to the $R$. rugosa flowers, they produced 3 times fewer stamens and almost 4 times fewer pistils. The measurements and photographs included in this paper show that the flowers of the species studied differ not only in size, but also in shape and petal color (Fig. 1a, Fig. 2a, Fig. 3a, Fig. 4a,b). We also found differences in the type of scent emitted by the petals. The $R$. $\times$ damascena flowers were characterized by the strongest scent with a rosy-fruity note. The flowers of $R$. gallica and $R$. rugosa emitted a medium strong scent, while the flowers of $R$. canina had the weakest scent.

\section{Petal anatomy}

The petal thickness in the investigated Rosa species ranged from 120 to $374 \mu \mathrm{m}$ (Tab. 3). The thickest petals were found in the flowers of $R$. × damascena, followed by R. rugosa. $R$. canina and $R$. gallica had a similar petal thickness which was at the same time the smallest.

The height of the papillae found on the adaxial surface of the petals and the width of the cuticular striae on their surface were compared (Tab. 3). The largest papillae $(28 \mu \mathrm{m})$ were found on the petals of $R$. gallica (Fig. $3 c, e, f$ ). In the case of R. ×damascena (Fig. 2 d,e) and R. rugosa (Fig. 4e-h), the papilla height reached similar values. The width of the cuticular striae on the papillae also significantly differed among the species (Tab. 3). The widest striae formed on the papillae of $R$. $\times$ damascena (Fig. $2 \mathrm{~b}-\mathrm{d}$ ), while the striae of $R$. canina had an almost twice smaller width (Fig. 1b-d).

It can be concluded based on the SEM analysis that the papillae of Rosa species differ not only in size but also in shape. In $R$. rugosa they narrow down towards the apex most (Fig. 4c-f,h), whereas in R. canina and $R . \times$ damascena they are the most rounded at the tip (Fig. 1b-d, Fig. 2b-d). The papillae on the petals of $R$. gallica (Fig. $3 \mathrm{~b}-\mathrm{f}$ ) show an intermediate form between the two above-mentioned species. Moreover, in R. canina high variation is observed in the size of the papillae located next to one another on the petals (Fig. 1b-d). The massive structure of the striae in $R$. $\times$ damascena can also be seen in the SEM images (Fig. 2b-d). A comparison of the petal cross sections for the four Rosa species reveals that the thickest petals, with the most dense arrangement of cells, are produced by R. ×damascena (Fig. 2e).

\section{Characteristics of pollen grains}

Rose pollen grains are tricolporate and round in shape, and have a striate exine (Fig. 5). In the species studied, the length of the polar axis in equatorial view was 29.4-33.5 $\mu \mathrm{m}$, whereas that of the equatorial axis in polar view ranged 29.2-34.2 $\mu \mathrm{m}$ (Tab. 4). Among the species studied, pollen grains of $R$. $\times$ damascena and $R$. gallica were largest. Generally, pollen grains of the investigated species can be considered to be medium. The $\mathrm{P} / \mathrm{E}$ ratio reached a value close to 1.0, which indicates the round shape of pollen grains. The pollen viability, as estimated using the acetocarmine method, ranged from $40 \%$ (R. canina) to $95 \%$ (R. rugosa; Tab. 5).

\section{Pollen production}

The pollen mass determined for 100 stamens ranged between $4.0 \mathrm{mg}$ (R. canina) and $10.3 \mathrm{mg}$ (R. rugosa; Tab. 5). Significant differences were found when the pollen mass was calculated per flower, which resulted from the varying numbers of stamens in the flowers. Three times more pollen was estimated for $R$. rugosa flowers (267 mg per 10 flowers) compared to $R$. × damascena flowers ( $89 \mathrm{mg}$ per 10 flowers). Much higher (eightfold) differences were found between the pollen content in the flowers of R. rugosa and R. canina.

\section{Pollen loads}

Bumblebees showed interest in pollen from the flowers of Rosa species and formed pollen loads. The mass of a pair of sampled and dried pollen loads ranged from $9.7 \mathrm{mg}$ to 50.5 $\mathrm{mg}$ (on average $30.3 \mathrm{mg}$ ). The smallest pollen loads were formed on the $R$. rugosa flowers, while the largest ones on the $R$. $\times$ damascena flowers. In both cases, the pollen load was sampled from Bombus sylvarum $\mathrm{L}$.

Tab. 2 Characteristics of the flowers of the four Rosa species.

\begin{tabular}{|c|c|c|c|c|c|c|c|c|}
\hline \multirow[b]{2}{*}{ Species } & \multirow{2}{*}{$\begin{array}{c}\text { Flower } \\
\text { diameter }(\mathrm{cm})\end{array}$} & \multirow{2}{*}{$\begin{array}{l}\text { Number } \\
\text { of petals }\end{array}$} & \multicolumn{3}{|c|}{ Number of stamens per flower } & \multicolumn{3}{|c|}{ Number of pistils per flower } \\
\hline & & & range & mean & $S D$ & range & mean & $S D$ \\
\hline Rosa canina & 5.7 & 5 & 73-91 & 83 & \pm 7 & $9-24$ & 17 & \pm 7 \\
\hline Rosa $\times$ damascena & 7.0 & 5 & $88-116$ & 103 & \pm 12 & $41-47$ & 43 & \pm 3 \\
\hline Rosa gallica & 5.5 & $22-35(28)$ & $146-179$ & 161 & \pm 11 & $37-44$ & 41 & \pm 3 \\
\hline Rosa rugosa & 11.0 & 5 & $240-279$ & 260 & \pm 14 & $46-82$ & 65 & \pm 13 \\
\hline Mean & & & & 151.8 & & & 41.5 & \\
\hline
\end{tabular}



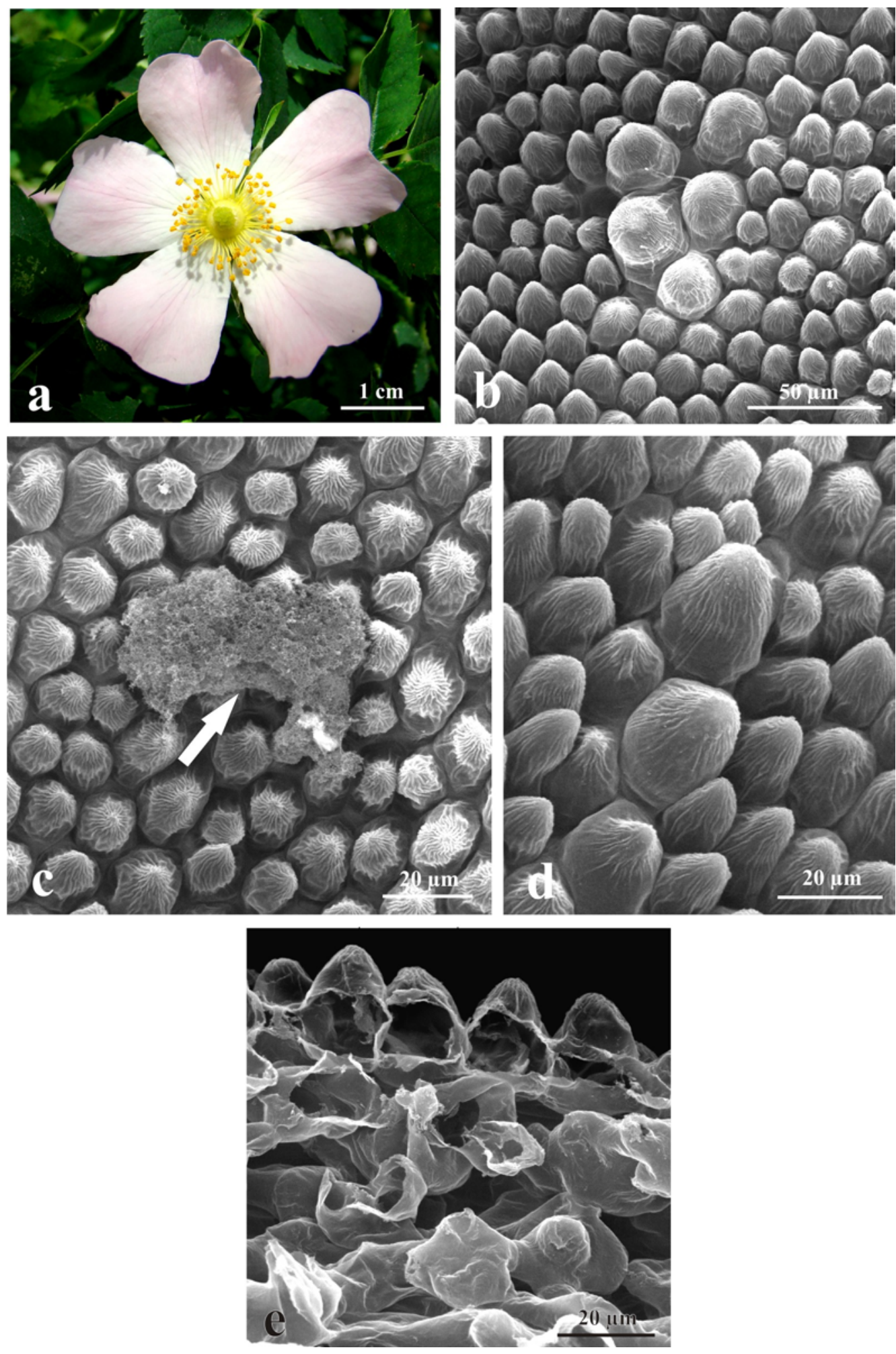

Fig. 1 Habit of the flower (a) and petals of Rosa canina (SEM). b-d Different sized papillae on the adaxial epidermis with a striated cuticle. Visible remnants of dried secretion (arrow; c). e Petal cross section showing a loose arrangement of mesophyll cells.

The color of the pollen loads sampled, as determined using A dictionary of color by Maerz and Paul [18], ranged between yellow amber and mustard green (T10/H-4 - T11/J-3).

The microscopic analysis of the samples of pollen loads revealed the presence of pollen of 16 taxa, including 10 belonging to nectariferous plants and 6 non-nectariferous plants (entomophilous or anemophilous). From 5 to 11 types of pollen were found in the individual samples. Rosa pollen grains were recorded in each pollen load sample and their participation was dominant, ranging from $88.61 \%$ to 

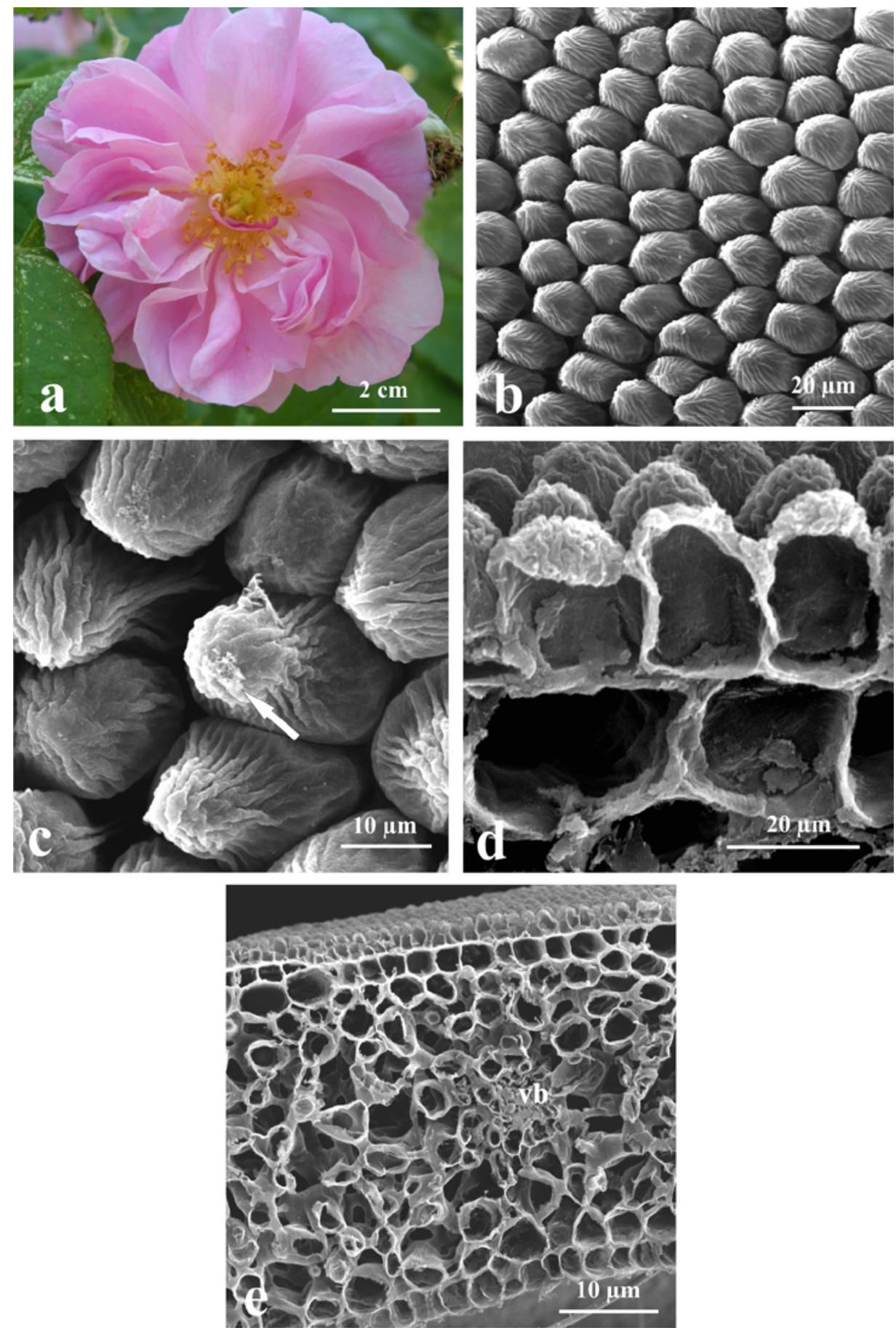

Fig. 2 Habit of the flower (a) and petal sections of Rosa $\times$ damascena (SEM). b,c Papillae from the adaxial surface of the petals with massive cuticular striae on the outer wall surface and remnants of dried secretion (arrow). d Partial cross section of outer tissues of the petal. e Petal cross section with a visible vascular bundle (vb).

97.94\% (Fig. 6, Fig. 7). The percentage of pollen belonging to the other taxa was low and corresponded to the groups of single pollen (3-16\%) or sporadic pollen (below 3\%).

\section{Discussion}

In the flowers of the genus Rosa, the perianth is situated at the apex of a green hypanthium (cup-shaped) that surrounds the gynoecium. The hypanthium in Rosa has to be interpreted as "a fusion product of leaf structures" on the basis of the vascular bundle system [26]. Among the Rosa species investigated, three species have 5 petals (R. canina, $R$. gallica, and $R$. rugosa), whereas $R$. $\times$ damascena produces many more petals (28) in several whorls. In addition to the petals of the corolla in this species, numerous petaloids can be found, which are intermediate forms of the stamens. The number of stamens in the flowers of the Rosa species 

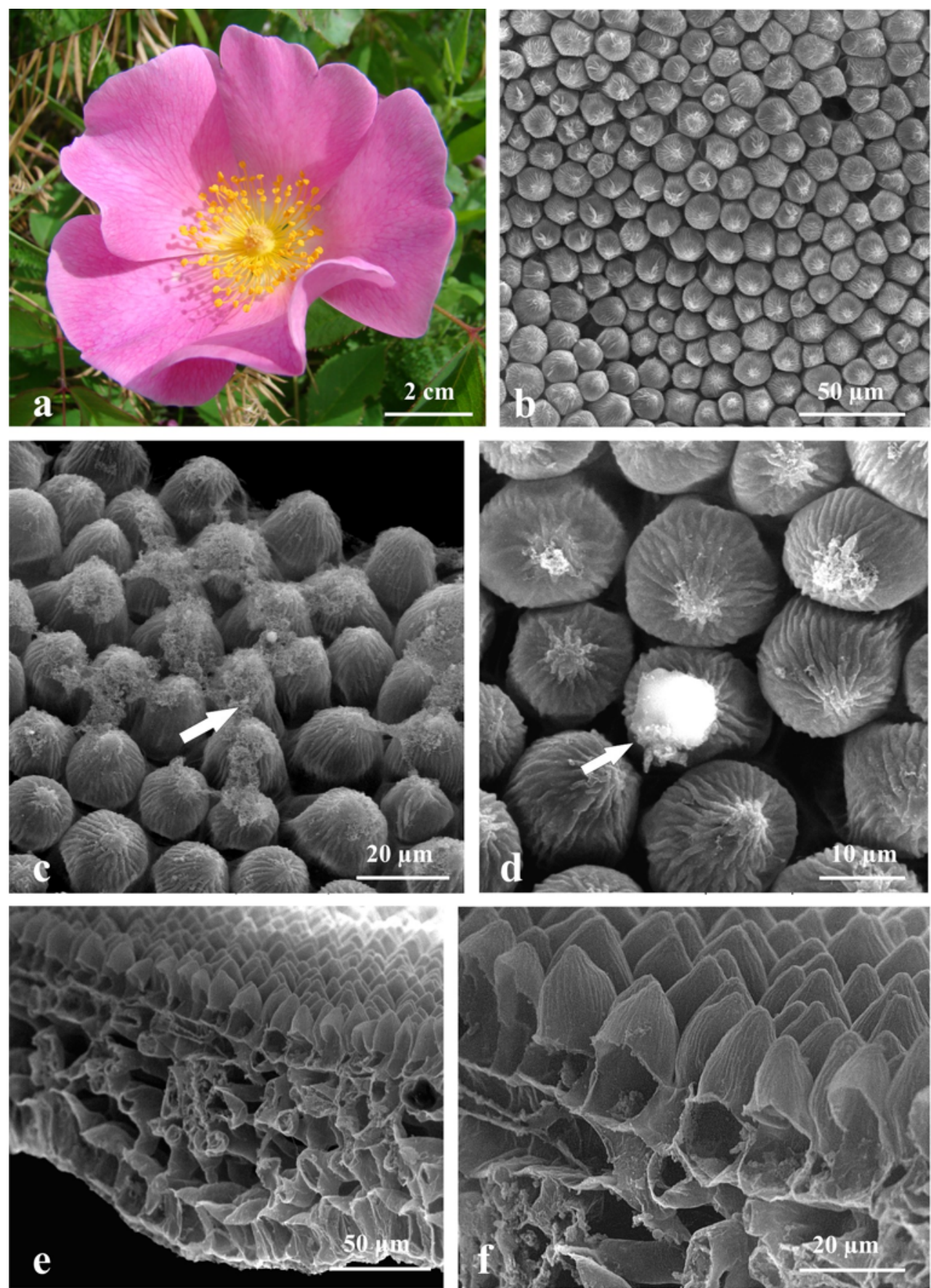

Fig. 3 Habit of the flower (a) and petal sections of Rosa gallica (SEM). b-d Papillae from the adaxial surface of the petals with a striated cuticle and remnants of dried secretion (arrows). e,f Petal cross sections.

investigated greatly varied, ranging 83-260 stamens. In terms of the increasing number of stamens, the species in question can be ranked as follows: $R$. canina, $R . \times$ damascena, R. gallica, R. rugosa.

Flower scents are most frequently secreted diffusely by the corolla epidermis. However, scent can also be produced by other parts of the flower. In R. rugosa and $R$. canina, the scent emitted by the flowers is dominated by terpenoid and benzenoid alcohols produced by the petals. Other parts of the flowers of these species produce scents with a different chemical composition. Sesquiterpenes have a major contribution to the scent of the sepals, while in the case of the anthers and pollen grains it has been found that there is a diversity of compounds, largely similar to those produced by the corolla $[27,28]$.

Among the Rosa species investigated in our study, $R$. $\times$ damascena was characterized by the most intense floral scent. It was classified as a rosy-fruity scent. Góra and Lis [5] report that among various floral scents of roses grown for essential oil, the scent of $R . \times$ damascena, which is described as a beautiful floral scent with a warm tea/honey undertone, is most appreciated. The floral scent of $R . \times$ damascena is 

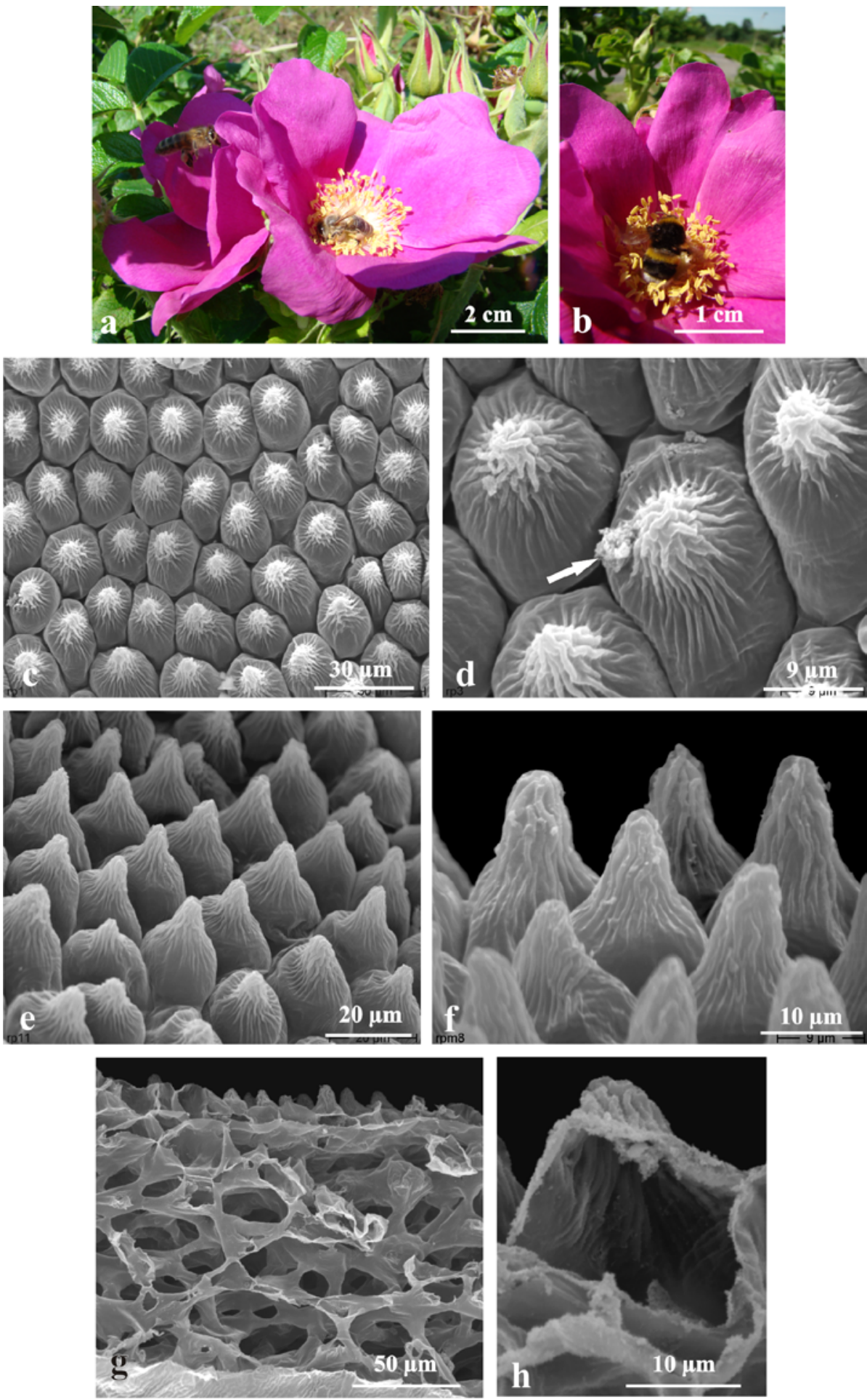

Fig. 4 Habit of the flowers visited by Apis mellifera and Bombus sp. (a,b) and petal sections of Rosa rugosa (SEM). c-f Papillae narrowing at the apex on the adaxial epidermis of the petals with visible striae and secretion remnants (arrow). g Petal cross section. $\mathbf{h}$ Enlargement of a longitudinal section of a papilla.

considered to be a standard for rose scent. According to these authors, in the petals of $R$. damascena var. kazanlik (Bulgaria) the average essential oil content is $0.035 \%$, which is one of the highest values found for the genus Rosa. In the oil obtained from $R . \times$ damascena flowers, the following monoterpenes predominate: citronellol and geraniol [5]. The above data concerning the type of scent of Rosa flowers correspond to the findings of Proctor et al. [28] who claim that the flowers that are more specially adapted to bees have a sweet or honey-like scent. The scents of R. gallica and 
Tab. 3 Anatomical features of the petals of the four Rosa species.

\begin{tabular}{|c|c|c|c|c|c|c|c|c|c|}
\hline \multirow[b]{2}{*}{ Species } & \multicolumn{3}{|c|}{ Petal thickness $(\mu \mathrm{m})$} & \multicolumn{3}{|c|}{ Papilla height $(\mu \mathrm{m})$} & \multicolumn{3}{|c|}{$\begin{array}{l}\text { Width of cuticular striae on papillae } \\
\qquad(\mu \mathrm{m})\end{array}$} \\
\hline & range & mean & $S D$ & range & mean & $S D$ & range & mean & $S D$ \\
\hline Rosa canina & $101.0-136.9$ & 119.9 & \pm 18.0 & $21.3-25.3$ & 23.4 & \pm 1.7 & $0.43-0.50$ & 0.46 & \pm 0.03 \\
\hline Rosa $\times$ damascena & $364.3-384.4$ & 374.4 & \pm 14.2 & $22.4-29.5$ & 25.8 & \pm 2.4 & $0.67-1.14$ & 0.94 & \pm 0.21 \\
\hline Rosa gallica & $116.7-126.7$ & 121.7 & \pm 7.1 & $25.8-29.7$ & 27.9 & \pm 1.5 & $0.66-0.91$ & 0.78 & \pm 0.11 \\
\hline Rosa rugosa & $106.5-160.0$ & 140.0 & \pm 24.6 & $22.2-28.7$ & 25.0 & \pm 2.1 & $0.60-1.01$ & 0.73 & \pm 0.13 \\
\hline
\end{tabular}
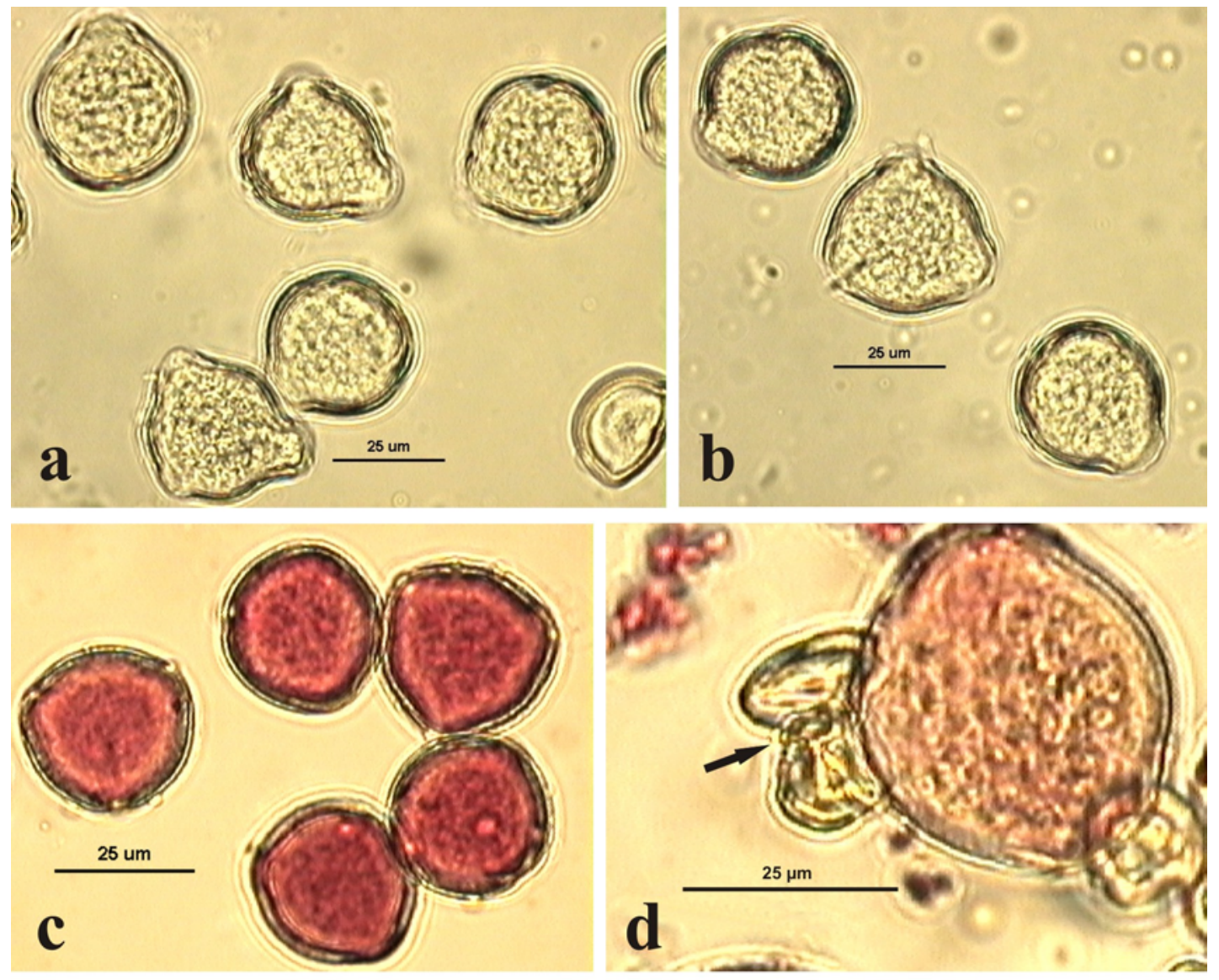

Fig. 5 Pollen grains. a,b Rosa sp. pollen grains in microscopic slides of different pollen loads sampled from Bombus sylvarum L. c Viable pollen grains of $R$. rugosa with a pink-stained protoplast after treating with acetocarmine. $\mathbf{d}$ Viable pollen grains of $R$. canina with a protoplast stained pink with acetocarmine as well as unstained and deformed non-viable pollen grains (arrow).

R. rugosa were determined in our research to be medium intense and this is also reflected in the data on the essential oil content in $R$. gallica petals $(0.017 \%)$ [5], which is much lower than in the case of $R$. $\times$ damascena. The $R$. canina flowers were characterized by the least intense scent. It is worth noting that this species is not mentioned among the roses used for the production of rose oil [5].

In the case of the $R . \times$ damascena flowers, the large number of petals and their considerable thickness as well as their intense scent confirm their usefulness as oil material. It has been shown that the highest content of rose oil, located mainly on the petal surface, is found in roses at the bud stage in early morning hours [5].

The present study found that each of the four Rosa species produces papillae of different shape and size. It is recognized that the role of the papillae produced in the petal epidermis is adaptation to entomophily as a foothold or as a light trap and petal reflexing $[28,29]$.

The length of the polar axis of pollen grains in the rose species studied was in the range of $23-43 \mu \mathrm{m}$, which proved to be wider compared to that given by Kirk [30] for various rose varieties $(24-36 \mu \mathrm{m})$. A wider size range was also 
Tab. 4 Dimensions of pollen grains of the four Rosa species.

\begin{tabular}{|c|c|c|c|c|c|c|c|}
\hline \multirow[b]{2}{*}{ Species } & \multicolumn{3}{|c|}{ Length of polar axis $(P ; \mu \mathrm{m})$} & \multicolumn{3}{|c|}{ Length of equatorial axis $(E ; \mu \mathrm{m})$} & \multirow[b]{2}{*}{$\mathrm{P} / \mathrm{E}$ ratio } \\
\hline & range & mean & $S D$ & range & mean & $S D$ & \\
\hline Rosa canina & $23.2-33.5$ & 29.4 & \pm 3.3 & $28.4-33.5$ & 29.7 & \pm 1.9 & 0.99 \\
\hline Rosa $\times$ damascena & $31.0-43.2$ & 33.5 & \pm 1.2 & $31.0-38.7$ & 34.2 & \pm 2.2 & 0.98 \\
\hline Rosa gallica & $25.8-31.0$ & 33.5 & \pm 2.2 & $25.8-33.5$ & 33.5 & \pm 3.1 & 1.00 \\
\hline Rosa rugosa & $25.8-31.0$ & 30.2 & \pm 1.7 & $28.4-31.0$ & 29.2 & \pm 1.3 & 1.00 \\
\hline Mean & & 31.7 & & & 31.6 & & 0.99 \\
\hline
\end{tabular}

Tab. 5 Pollen value of the four Rosa species.

\begin{tabular}{|c|c|c|c|c|c|c|c|c|c|}
\hline \multirow[b]{2}{*}{ Species } & \multicolumn{3}{|c|}{ Pollen mass per 100 stamens (mg) } & \multicolumn{3}{|c|}{ Pollen mass per 10 flowers (mg) } & \multicolumn{3}{|c|}{ Viability of pollen grains (\%) } \\
\hline & range & mean & $S D$ & range & mean & $S D$ & range & mean & $S D$ \\
\hline Rosa canina & $3.30-4.63$ & 4.00 & \pm 0.53 & $27.39-38.18$ & 33.20 & \pm 4.45 & $26.7-48.8$ & 40.0 & \pm 9.6 \\
\hline Rosa $\times$ damascena & $7.89-9.29$ & 8.65 & \pm 0.58 & $81.27-95.69$ & 89.12 & \pm 6.01 & $56.9-61.3$ & 59.3 & \pm 1.7 \\
\hline Rosa gallica & $4.92-8.88$ & 7.36 & \pm 0.62 & $79.22-127.19$ & 131.54 & \pm 9.99 & $34.1-51.1$ & 42.0 & \pm 7.1 \\
\hline Rosa rugosa & $9.17-12.09$ & 10.27 & \pm 1.33 & $238.42-313.04$ & 267.02 & \pm 34.64 & $91.6-96.8$ & 94.8 & \pm 2.6 \\
\hline Mean & & 7.57 & & & 130.21 & & & 59.0 & \\
\hline
\end{tabular}

obtained in the case of $R$. canina pollen grains (23.2-33.5 $\mu \mathrm{m})$ compared to the data reported by Ricciardelli d'Albore [24] (31.4-32.6 $\mu \mathrm{m})$, but it was smaller than that given by Beug [31] (30.5-40.5 $\mu \mathrm{m})$. In our study, the dimensions of the polar axis in R. gallica were in the range of 25.8-31.0 $\mu \mathrm{m}$, whereas Beug [31] found a range of 28.1-38.6 $\mu \mathrm{m}$ for the pollen of this species.

In this research, the shape of pollen grains was determined to be round or close to round, as indicated by the $\mathrm{P} / \mathrm{E}$ ratio ranging from 0.99 to 1.00 . The ratio of 0.99 obtained for $R$. canina was slightly higher compared to the value of 0.96 that is reported for this species by Ricciardelli d'Albore [24].

In terms of apicultural usefulness, the flowers of wild roses are treated as polleniferous flowers, since they do not produce nectar [3,32]. Dobson et al. [33] emphasise that in the case of $R$. rugosa the main stimulus that attracts bumblebees is the pollen odor and the visual attractiveness of the anthers, whereas the petal color and scent play a secondary role. Cultivated roses are not important as a source of food for insects due to numerous petals and a low number of stamens. Some authors report that the rose flowers produce small amounts of nectar [3,30,34].

A large number of stamens in the flower frequently determines an abundant mass of pollen [28,35]. We found that the $R$. rugosa flowers, which had the highest number of stamens (260) among the species investigated, produced the highest mass of pollen (26.7 mg per flower). Very diverse results concerning the abundance of pollen in the latter mentioned species can be found in the literature. Jabłoński [36] reports that $R$. rugosa produces $19.1 \mathrm{mg}$ of pollen per flower, whereas Lipiński [3] mentions a pollen mass of 45.9 mg per flower. The significant divergence in the results obtained by individual authors may arise from different soil nutrient availability and from the impact of weather conditions on the plants before and during flowering [36,37]. We found the lowest pollen mass in the flowers of R. canina (3.3 mg per flower). Rawski [34] also concluded that the flowers of $R$. canina are poor in pollen, giving them the lowest value on a three-level scale. A much lower mass of pollen was shown for $R$. multiflora (2.0 mg per flower) whose flowers had a similar number of stamens as the flowers of $R$. canina, but a much smaller corolla diameter [37].

The presence of Rosa pollen grains in samples of insect pollen loads [38,39] and in honey samples $[40,41]$ is a confirmation of the attractiveness of pollen rewards to insects. The pollen loads formed by bumblebees which were sampled in this study had different shades of color, from yellow amber to mustard color. According to Hodges [21] and Kirk [30], bee loads of Rosa pollen are dark orange or even brownish. Ricciardelli d'Albore [24] reports that insects forage on Rose form slightly pink loads. Lipiński [3] finds that pollen loads collected from the same plant species can have a different color, depending whether the bee gathered pollen from open anthers or extracted it by gnawing through the anther walls. Their color can also be affected by the color of honey used by bees to moisten the pollen [42]. 


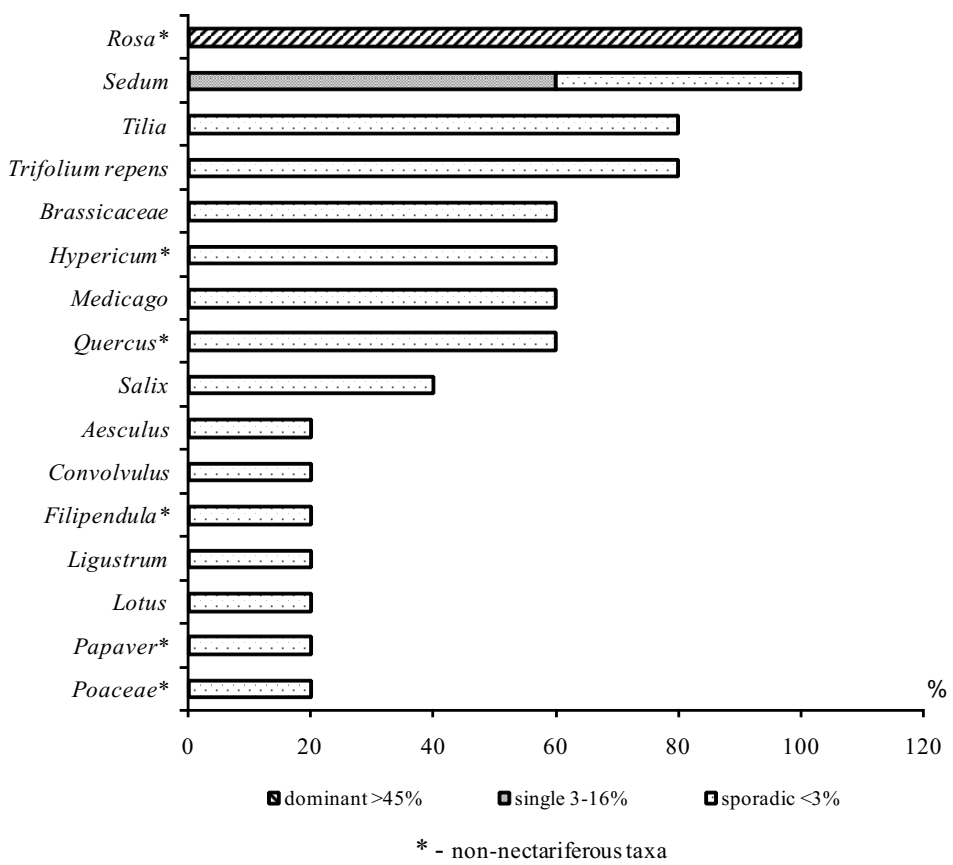

Fig. 6 Pollen frequency and percentages in pollen loads sampled from Bombus sylvarum L.

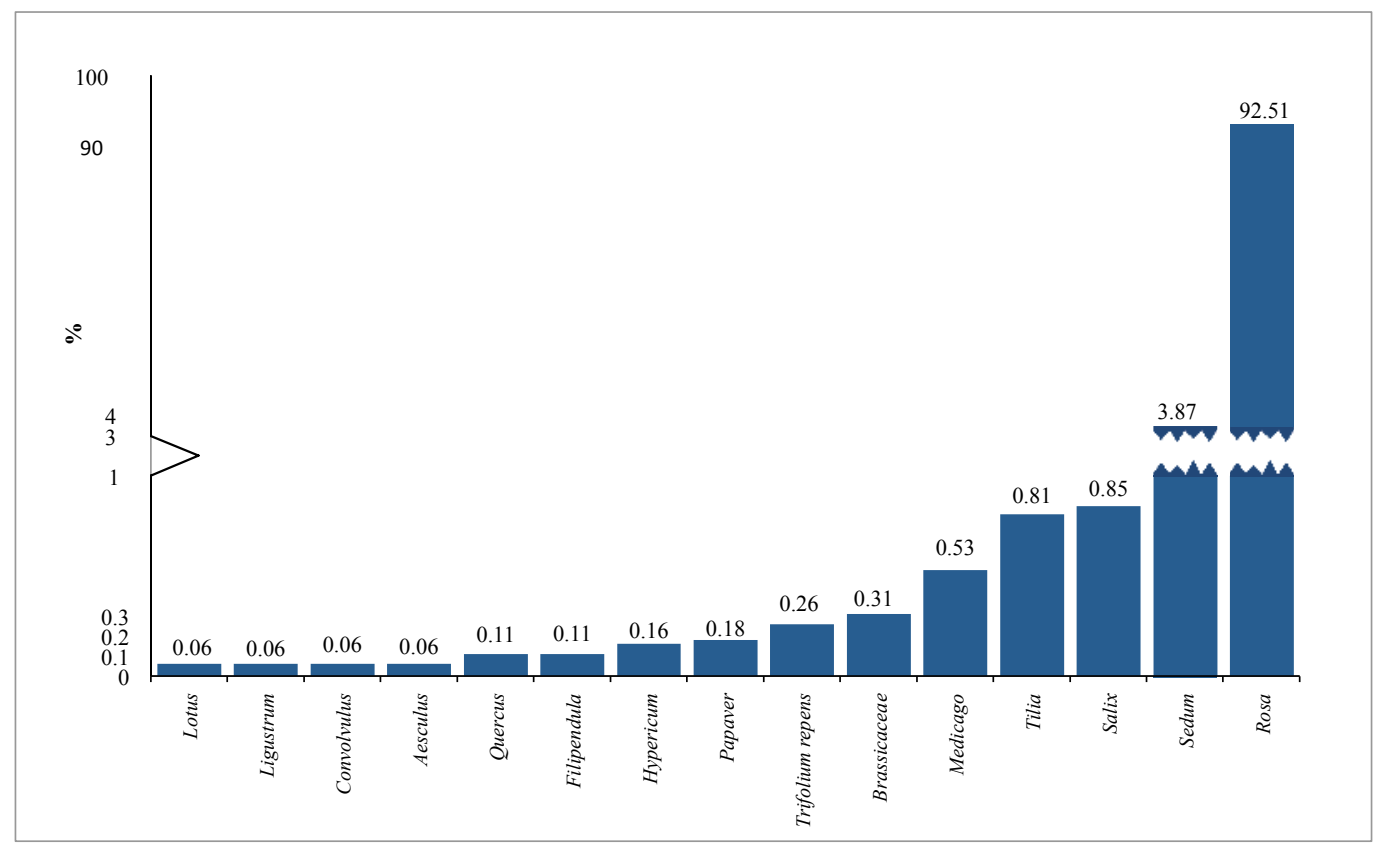

Fig. 7 Percentage participation of pollen of the individual taxa in pollen loads from Bombus sylvarum L.

\section{Conclusions}

1. Due to their largest biomass (the number and thickness of petals), the $R$. ×damascena flowers with an intense scent can be abundant raw material for the production of rose oil.

2. The scent-emitting papillae that are found on the adaxial surface of the petals differ in size and shape in the species studied.
3. Among the Rosa species investigated, R. rugosa is characterized by the highest apicultural value due to the production of the highest mass of pollen, the longest flowering period as well as the greatest flower diameter.

4. Rosa pollen predominated (over 90\%) in the pollen loads of bumblebees visiting two of the Rosa species investigated, which may be evidence of its attractiveness to insects. 


\section{Acknowledgments}

Research supported by Poland's Ministry of Science and Higher Education as part of the statutory activities of the Department of Botany, University of Life Sciences in Lublin.

\section{Authors' contributions}

The following declarations about authors' contributions to the research have been made: idea of the study: EWC; microscopical analysis: AS, BŻ, ES, EWC; photographs: AS, ES; writing of the manuscript: AS, BŻ, ES, EWC.

\section{Competing interests}

The following declarations about authors' competing interests have been made: EWC is a honorary editor of the Acta Agrobotanica; AS is a secretary of the Acta Agrobotanica Editorial Council; other authors: no competing interests.

\section{References}

1. Szweykowska A, Szweykowski J, editors. Słownik botaniczny. Warszawa: Wiedza Powszechna; 2003.

2. Rutkowski L. Klucz do oznaczania roślin naczyniowych Polski niżowej. Warszawa: Państwowe Wydawnictwo Naukowe; 2008.

3. Lipiński M. Pożytki pszczele: zapylanie i miododajność roślin. Warszawa: Powszechne Wydawnictwo Rolnicze i Leśne; 2010.

4. Zając A, Zając M, editors. Distribution atlas of vascular plants in Poland. Cracow: Laboratory of Computer Chorology, Institute of Botany, Jagiellonian University; 2001.

5. Góra J, Lis A. Najcenniejsze olejki eteryczne. Toruń: Wydawnictwo Uniwersytetu Mikołaja Kopernika; 2005.

6. Bruun HH. Prospects for biocontrol of invasive Rosa rugosa. BioControl. 2006;51:141-181. http://dx.doi.org/10.1007/s10526-005-6757-6

7. Weidema I. NOBANIS - invasive alien species fact sheet - Rosa rugosa [Internet]. Online Database of the European Network on Invasive Alien Species - NOBANIS; 2006 [cited 2015 Jun 12]; Available from: http://www.nobanis.org

8. Tokarska-Guzik B, Dajdok A, Zając M, Zając A, Urbisz A, Danielewicz W, Hołdyński C. Rośliny obcego pochodzenia w Polsce. Warszawa: Generalna Dyrekcja Ochrony Środowiska; 2012.

9. Strzelecka H, Kowalski J. Encyklopedia zielarstwa i ziołolecznictwa. Warszawa: Wydawnictwo Naukowe PWN; 2000.

10. Czerpak R, Jabłońska-Trypuć A. Roślinne surowce kosmetyczne. Wrocław: MedPharm Polska; 2008.

11. Romer M. Aromaterapia, leksykon roślin leczniczych. Wrocław: MedPharm Polska; 2009.

12. Dobson HEM, Bergström G, Groth I. Differences in fragrance chemistry between flower parts of Rosa rugosa Thunb. (Rosaceae). Israel J Bot. 1990;39:143-156.

13. Bergougnoux V, Caissard JC, Jullien F, Magnard JL, Scalliet G, Cock $\mathrm{JM}$, et al. Both the adaxial and abaxial epidermis layers of the rose petal emit volatile scent compounds. Planta. 2007;226:853-866. http:// dx.doi.org/10.1007/s00425-007-0531-1

14. Sulborska A, Weryszko-Chmielewska E, Chwil M. Micromorphology of Rosa rugosa Thunb. petal epidermis secreting fragrant substances. Acta Agrobot. 2012;65(4):21-28. http://dx.doi.org/10.5586/aa.2012.018

15. Łukasiewicz A. Potrzeba ujednolicenia metodyki fenologicznej w Polskich Ogrodach Botanicznych i Arboretach. Wiad Bot. 1984;28(2):153-158.

16. Warakomska Z. Badania nad wydajnością pyłkową roślin. Pszczelnicze Zeszyty Naukowe. 1972;16:63-90.

17. Szklanowska K. Pollen flows of crowfoot family (Ranunculaceae L.) from some natural plant communieties. In: Banaszak J, editor Changes in fauna of wild bees in Europe. Bydgoszcz: Pedagogical University; 1995. p. 201-209.

18. Maerz A, Paul M. A dictionary of color. New York, NY: McGraw-Hill Co.; 1950.

19. Smaragdova NP. Izbiratelnaja sposobnost pčeł pri opylenii rastenji. Trudy Agrobiolog. Stancji Biologo-počviennovo Fakulteta. 1956;180(2):97-102.

20. Moar NT. Pollen analysis of New Zealand honey. N Z J Agric Res. 1985;28:39-70. http://dx.doi.org/10.1080/00288233.1985.10426997

21. Hodges D. The pollen loads of the honeybee. London: IBRA; 1952.

22. Sawyer R, Pickard RS. Pollen identification for beekeepers. Cardiff: University College Cardiff Press; 1981.

23. Sawyer R. Honey identification. Cardiff: Cardiff Academic Press; 1988.

24. Ricciardelli d'Albore G. Mediterranean melissopalynology. Perugia: Università degli studi di Perugia, Facoltà di agraria, Istituto di entomologia agraria; 1998.

25. Bucher E, Kofler V, Vorwohl G, Zieger E. Das Pollenbild der Südtirolen Honige. Leifers: Biologisches Labor der Landesagentur für Umwelt und Arbeitsschutz; 2004

26. Weberling F. Morphology of flowers and inflorescences. Cambridge: Cambridge University Press; 1989.

27. Bergström G. Chemical ecology of terpenoid and other fragrances of angiosperms. In: Harborne JB, Tomas-Barberan FA, editors. Ecological chemistry and biochemistry of plant terpenoids. Oxford: Clarendon Press; 1991. p. 287-296. (Proceedings of the Phytochemical Society of Europe; vol 31)

28. Proctor M, Yeo P, Lack A. The pollination of flowers. Portland, OR: Timber Press; 1996.

29. Whitney HM, Bennett KMV, Dorling M, Sanbach L, Prince D, Chittka $\mathrm{L}$, et al. Why do so many petals have conical epidermis cells? Ann Bot. 2011;108:609-616. http://dx.doi.org/10.1093/aob/mcr065

30. Kirk WDJ. A colour guide to pollen loads of the honey bee. Cardiff: International Bee Research Association; 1994

31. Beug HJ. Leitfaden der Pollenbestimmung für Mitteleuropa und angrenzende Gebiete. München: Verlag Dr. Friedrich Pfeil; 2004.

32. Maurizio A, Grafl I. Das Trachtpflanzenbuch. Nektar und Pollen die wichtigsten Nahrungsquellen der Honigbiene. München: Eherenwirth; 1969.

33. Dobson HEM, Danielson EM, van Wesep ID. Pollen odor chemicals as modulators of bumble bee foraging on Rosa rugosa Thunb. (Rosaceae). Plant Species Biol. 1999;14(2):153-166. http://dx.doi. org/10.1046/j.1442-1984.1999.00020.x

34. Rawski W. Pożytek pszczeli. Cz. III. Wartość pożytkowa roślin dzikich i uprawnych. Warszawa: ExLibris; 1948

35. Buchmann SL. Buzz pollination in angiosperms. In: Jones CE, Little RJ, editors. Handbook of experimental pollination biology. New York, NY: Scientific and Academic Editions; 1983.

36. Jabłoński B. Wiadomości z botaniki pszczelarskiej. In: Prabucki J, editor. Pszczelnictwo J. Szczecin: Wydawnictwo Promocyjne "Albatros"; 1998.

37. Szklanowska K, Strzałkowska M. Blooming biology and flow value of Rosa multiflora Thunb. shrubs. Ann Univ Mariae Curie-Skłodowska E Agric. 2001;9:33-41.

38. Chaturvedi M. An analysis of honey bee pollen loads from Banthra, Lucknow, India. Grana. 1973;13:139-144. http://dx.doi. org/10.1080/00173137309429890

39. Noor MJ, Khan MA, Camphor ES. Palynological analysis of pollen loads from pollen source of honeybees in Islamabad, Pakistan. Pak Bot. 2009;41(2):495-501.

40. Stawiarz E. Pollen of non-nectariferous plants in the microscopic image of honeys of some communes of the Świętokrzyskie Voivodeship. Acta Agrobot. 2009;62(2):53-58. http://dx.doi.org/10.5586/aa.2009.026

41. Tiwari JK, Gairola A, Tiwari P, Ballabaha R. Pollen analysis of some honey samples from District Uttarakashi in Garhwal Himalaya India. Asian J Exp Biol Sci. 2012;3(4):778-784.

42. Paradowska K, Zielińska A, Krawiec N. Skład i właściwości antyoksydacyjne barwnych frakcji wyodrębnionych z pszczelego pyłku kwiatowego. Postępy Fitoterapii. 2014;4:209-215. 


\section{Biologia kwitnienia i produkcja pyłku czterech gatunków z rodzaju Rosa L.}

\section{Streszczenie}

Dziko rosnące gatunki z rodzaju róża (Rosa) mają duże znaczenie jako źródło pyłku dla owadów. Uzyskiwany z płatków olejek znalazł zastosowanie w perfumerii, przemyśle kosmetycznym i lecznictwie. W pracy porównano długość okresów kwitnienia, długość życia kwiatów, liczbę pręcików i słupków, masę i wielkość ziaren pyłku oraz cechy anatomiczne płatków czterech gatunków z rodzaju Rosa: $R$. canina, $R$. ×damascena,
R. gallica i $R$. rugosa. Wykazano różna długość życia kwiatów badanych róż (3.5-8 dni) oraz duże zróżnicowanie w liczbie pręcików (82-260) i słupków (17-65), a także w masie produkowanego pyłku. Najwięcej pyłku wytwarzają kwiaty $R$. rugosa $(26.7 \mathrm{mg} / \mathrm{kwiat})$, najmniej kwiaty $R$. canina (3.3 mg/kwiat), co jest związane w dużej mierze $\mathrm{z}$ różną pomiędzy gatunkami liczbą pręcików w kwiatach. Największe ziarna pyłku stwierdzono u $R$. ×damascena i $R$. gallica. Wśród badanych gatunków róż najgrubsze płatki wytwarza $R$. $\times$ damascena, a występujące na doosiowej powierzchni płatków papille emitujące zapach różnią się wielkością i kształtem. Udział pyłku Rosa w obnóżach pyłkowych zebranych przez trzmiele oblatujące kwiaty róż jest dominujący i wynosi $>90 \%$. 